\title{
Soybean yield loss and economic thresholds due to glyphosate resistant hairy fleabane interference
}

\section{Perda de rendimento da soja e nível de dano econômico pela interferência de buva resistente ao glifosato}

\author{
Dirceu Agostinetto ${ }^{*}$, Diecson Ruy Orsolin da Silva², Leandro Vargas

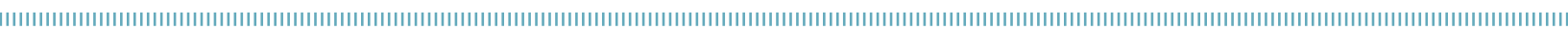

\begin{abstract}
The interference of glyphosate resistant hairy fleabane (Conyza bonariensis) has caused yield losses in soybean crop. Knowledge of the economic threshold is an important aspect for the economic management of resistant weeds. Because of it, the interference of the glyphosate resistant hairy fleabane density on the soybean yield loss was evaluated, as well as to estimate the economic threshold. Two experiments were conducted to verify the effect of different weed densities on the yield of two soybean cultivars (BRS Estância and BMX Turbo). Weed density ranged from 0 to 124 plants $\mathrm{m}^{-2}$. The yield of the BRS Estância decreased by $1.4 \%$ to the increase of one single plant, while for the BMX Turbo the loss was $25.9 \%$. Soybean yield and economic threshold were lower for the BMX Turbo cultivar compared to the cultivar BRS Estância, which can be attributed to the genotype, competitive ability, weed development stage and/or environment. Increases in crop yield expectation, soybean price and herbicide efficiency reduce the economic threshold, indicating that the adoption of control measures should be taken when the weed density is low. Due to the high cost of hairy fleabane control, it is only feasible at high densities.
\end{abstract}

KEYWORDS: Conyza bonariensis; weed control cost; competition; weed density; rectangular hyperbole.
RESUMO: A interferência de plantas de buva (Conyza bonariensis) resistente ao herbicida glyphosate tem causado perdas de produtividade na cultura da soja. O conhecimento do nível de dano econômico é um importante fator para o manejo econômico de plantas daninhas resistentes na cultura da soja. Para isso, foi avaliada a interferência da densidade de buva resistente ao glyphosate sobre a perda de rendimento da soja, bem como estimado o nível de dano econômico. Dois experimentos foram conduzidos para verificar o efeito de diferentes densidades da planta daninha sobre a produtividade de dois cultivares de soja (BRS Estância e BMX Turbo). As densidades de buva variaram de 0 a 124 plantas $\mathrm{m}^{-2}$. A produtividade do cultivar BRS Estância reduziu 1,4\% ao aumento de uma planta, enquanto para o cultivar BMX Turbo a perda foi de $25,9 \%$. A produtividade da soja e o nível de dano econômico foram menores para o cultivar BMX Turbo, em comparação com o cultivar BRS Estância, o que pode ser atribuído ao genótipo, à habilidade competitiva, ao estádio de desenvolvimento da buva e/ou a ambiente. Aumentos na expectativa de produtividade da cultura, no preço da soja e na eficiência dos herbicidas reduzem o nível de dano econômico, indicando que a adoção de medidas de controle deve ser tomada quando a população de buva é baixa. Em funçáo do elevado custo de controle da buva, este somente é viável em altas densidades.

PALAVRAS-CHAVE: Conyza bonariensis; custo de controle de planta daninha; competição; densidade de planta daninha; hipérbole retangular. 


\section{INTRODUCTION}

Soybean is one of the most important cultivated crop in the world, being weed competition by water, nutrients and light one of the main factors that contribute to the decrease of crop yield. In crop systems, such as soybeans, chemical control by herbicides has been the main practice in weed management.

The widespread adoption of glyphosate resistant crops, Roundup Ready ${ }^{\circledast}$ soybean (RR), brought benefits to farmers, is strictly an effective herbicide for weed management, making the time application more flexible, as well as reducing weed control costs. However, the emergence of glyphosate resistant weeds has increased production costs due to the need to alternate other herbicides.

The hairy fleabane (Conyza bonariensis L. Cronquist) was the first reported case of resistance to glyphosate resistant soybean in Brazil (VARGAS et al., 2007). The herbicide management of this weed is mainly focused on the control of plants that emerge in the pre-crop period, since the greatest germinative flow of hairy fleabane typically occurs in late autumn and winter (LAZAROTTO et al., 2008). This plant has been a major problem for farmers because it causes high injury to the crop and presents great capacity to infest adjacent areas due to seed production and dispersal capacity (DAUER et al., 2009; SHRESTHA et al., 2010; TREZZI et al., 2013).

The estimation of crop yield loss due to weed interference and determination of economic thresholds (ET) are important for the decision making of the adoption of integrated weed management (GHEREKHLOO et al., 2010). Economic models based on the ET help decision making to mediate the control of a certain weed density. Therefore, ET is characterized by the use of control methods on the plant density when the damage caused in grain yield is higher than the cost of the control measures to be adopted (COUSENS, 1985).

The integrated weed management should be adopted, so that weed densities are below the level of ET. In addition to herbicides, others practices of integrated weed management can be used, such as sowing time, crop density, rows spacing and fertilization in the growing line. In general, hairy fleabane must be controlled from 24 days after the emergence of soybean (SILVA et al., 2014). Thus, the use of strategies in integrated weed management is essential to contain weed-related costs and environmental resistance and contamination problems in order to maximize weed management (LAMEGO et al., 2013).

One of the difficulties related to the lack ET adoption by producers refers to the wide diversity of weeds occurring in the area, since the yield loss and herbicide efficiency are dependent on weed that interfere with crops. Among other limitations of ET are the low ability to predict weed damage, instability of biological variables between agricultural and local years, economic market oscillations that influence the prices of agricultural products and agricultural inputs, and ecological consequences to medium and long times, especially with regard to the offspring of individuals (KALSING; VIDAL, 2010).

ET is a useful tool for producers in decision making to intervene in weed management based on information on expected crop yield, price offered by grains, control costs and herbicide efficiency. Therefore, the objectives of the work were to evaluate interference of the diferent densities of glyphosate resistant hairy fleabane on soybean yield loss, as well as to estimate the level of economic thresholds.

\section{MATERIAL AND METHODS}

Two field experiments were carried out in two locations,

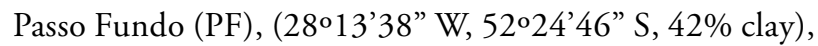

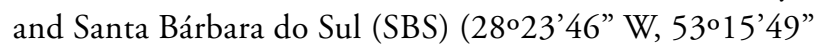
S, 32\% Clay), both locations on Rio Grande do Sul (RS), Brazil, in the crop season 2011/12. The soil of the areas is classified as typical dystrophic red latosol. The climate in the locations where the experiments were conducted, according to Köppen's Climate classification, is humid subtropical climate (CFA).

The experiments design was randomised blocks design with three replicates. Hairy fleabane density $(C$. bonariensis) were established by the natural infestation found in the both areas. In the experiment in PF, 10 hairy fleabane density were used: $0,7,10,15,25,33,63,78,116$ and 124 plants $\mathrm{m}^{-2}$; in the experiment in SBS, 11 density were used: $0,2,4,5$, $10,20,30,40,50,60$ and 100 plants $\mathrm{m}^{-2}$. The experimental units measured $5.4 \mathrm{~m}^{2}(1.8 \times 3 \mathrm{~m})$ with four rows of soybean spacing $0.45 \mathrm{~m}$.

The area of the PF was installed in the fallow area, and before sowing it was applied the sequential herbides glyphosate at 1,080 g ae ha-1 (Gliz $480 \mathrm{SL})+$ cletodim at $120 \mathrm{~g}$ ae ha ${ }^{-1}$ (Select $240 \mathrm{SC}$ ) at 85 and 23 days before sowing (DBS), and only hairy fleabane plants resistant to glyphosate remaining. The cultivar BRS Estância RR (high branching and GM 6.1) was planted on 24 October, 2011 at a seeding rate 210,000 seeds ha ${ }^{-1}$, and for soil fertilizer was used $60 \mathrm{~kg}$ of $\mathrm{P}_{2} \mathrm{O}_{5}$ and $90 \mathrm{~kg}$ of $\mathrm{K}_{2} \mathrm{O} \mathrm{ha}^{-1}$ in the seeding row. After the soybean emergence, two applications of glyphosate at $720 \mathrm{~g}$ ae $\mathrm{ha}^{-1}$ (Gliz $480 \mathrm{SL}$ ) were carried out at 14 and 28 days after soybean emergence (DAE). In SBS it was installed in an area with a mixed vegetation cover composed of oats (Avena strigosa) and ryegrass (Lolium multiflorum), and to desiccate the area it was used glyphosate at $1,080 \mathrm{~g}$ ae $\mathrm{ha}^{-1}$ (Gliz $480 \mathrm{SL}$ ) at 71 and 10 DBS. The cultivar BMX Turbo RR (low braching and GM 5.8) was planted on 28, November 2011 at a seeding rate with 290,000 seeds $\mathrm{ha}^{-1}$. For fertilizer, it was used $70 \mathrm{~kg}$ of $\mathrm{P}_{2} \mathrm{O}_{5}$ and $70 \mathrm{~kg}$ of $\mathrm{K}_{2} \mathrm{O} \mathrm{ha}^{-1}$ in the seeding row. The weed management on postemergence soybean were performed by handling. In all trials, 
the herbicide application was performed with spray monted on tractor delivering a spray volume of $100 \mathrm{~L} \mathrm{ha}^{-1}$.

The hairy fleabane density were evaluated at the time of soybean emergence (PF) and at 5DAE (SBS), when hairy fleabane plants were on average of 15 and $30 \mathrm{~cm}$ height, respectively. Plants presented in the all experimental unit were counted for subsequent thinning, leaving the number of plants for the desired density.

The yield components (pods per linear meter, number of grains per pods and weight of a thousand grains) were evaluated in a sowing line. Soybean grain yield was determined in an area of $2.25 \mathrm{~m}^{2}(0.90 \times 2.5 \mathrm{~m})$, two central rows of the experimental unit were harvested, and after grain weighing it was determined to grain moisture and corrected to $13 \%$ and yield expressed in $\mathrm{kg} \mathrm{ha}^{-1}$.

The data were submitted to analysis of variance by the $\mathrm{F}$ test with a 5\% error probability level, and with significance. The yield components data was applied exponential regression (Equation1):

$y=y 0+a^{*} \exp \left(-b^{*} x\right)$

In which:

y0 = maximum asymptote;

$a$ and $b=$ parameters of the equation and

$\mathrm{x}=$ hairy fleabane density.

The grain yield data were transformed into a percentage value relative to the control without the presence of the weed, and adjusted to the nonlinear regression model of the rectangular hyperbola proposed by Equation 2 COUSENS (1985), that describes the behavior of the grain yield as a function of the level of weed infestation:

$\mathrm{Yl}=[i . \mathrm{P}] /[1+(i / a) . \mathrm{P}]$

In which:

$\mathrm{Yl}=$ yield loss, expressed as a percentage, relative to control yield without infestation;

$\mathrm{P}=$ weed density and

$i$ and $a=$ the yield loss per unit of weed when the value of the variable approached zero or when it tends to infinity, respectively.

The adjustment of the data to the model was performed by the PROC NLIN procedure of the Statistical Analysis System (SAS) computer program, and the graphs were constructed by SigmaPlot 10. Also, the yield loss curves were segmented into linear equations to obtain the slopes of each segment of the line. The criterion of better fit of the data to the model was based on the higher coefficient of determination $\left(\mathrm{R}^{2}\right)$ and the lower value of the residue mean square (MSR). To calculate the economic thresholds, we used the estimates of parameter $i$ obtained from the equation cited before and the Equation 3 adapted from LINDQUIST; KROPFF (1996):
$\mathrm{ET}=\mathrm{Wc}_{\mathrm{c}} /[$ Yg. Sp. $(i / 100) .(\mathrm{H} / 100)]$

In which:

$\mathrm{ET}=$ economic thresholds (plants $\mathrm{m}^{-2}$ );

$\mathrm{Wc}=$ weed control cost (herbicide and application, in reais ha $\left.{ }^{-1}\right)$;

$\mathrm{Yg}=$ soybean yield grains $\left(\mathrm{kg} \mathrm{ha}^{-1}\right)$;

$\mathrm{Sp}=$ soybean prices $\left(\mathrm{R} \$ \mathrm{~kg}^{-1}\right)$;

$i=$ soybean loss yield (\%) per competition plant unit when the density level approaches zero and

$\mathrm{H}=$ herbicide efficiency (\%).

For ET calculation purposes, three values were estimated for soybean yield potencial, soybean prices, control cost, and herbicide efficiency in hairy fleabane. The yield potencial of soybean was estimated in 2,000, 3,500 and 5,000 $\mathrm{kg} \mathrm{ha}^{-1}$ (which are the average soybean grain yield observed in the last five growing season in Brazil) (CONAB, 2016). The prices offered by soybean were between $\mathrm{R} \$ 40,60$ and $80 \mathrm{bags}^{-1}$, based on the minimum and maximum prices observed in Rio Grande do Sul between February 2011 and February 2016 (AGROLINK, 2016). The weed control cost varied from $\mathrm{R} \$ 50,100$ to 150 , taking into account the average price of recommended herbicides for soybean pre-sowing management for control of glyphosate resistant hairy fleabane and the application costs (tractor + sprayer). The herbicide efficiency adopted was 80,90 and $100 \%$ control of the plants.

\section{RESULTS AND DISCUSSION}

Among the components of soybean yield, only the number of pods was affected by the increase in hairy fleabane density. The increase of the hairy fleabane density on both soybean cultivars caused an exponential reduction in the number of pods, with a tendency to stabilize the damages in the largest hairy fleabane densities (Fig. 1). The impact of the reduction in the number of pods was more pronounced in the BMX Turbo cultivar. The BRS Estância cultivar is characterized by high branching, which can result in greater productive and competitive potential with weeds. Also, the amount of branching produced by the plants increases the number of reproductive structures, and the consequent number of pods in the plants. Thus, plants more productive in biomass tend to be more tolerant to weed competition, as well as the morphological characteristics of soybean plants as amount and length of branches (BIANCHI et al., 2006).

The grain yields observed in the absence of hairy fleabane were 2,894 and 1,532 $\mathrm{kg} \mathrm{ha}^{-1}$ for the BRS Estância and BMX Turbo cultivars, respectively. The low soybean yield for BMX Turbo cultivar could be due to the genetic characteristics of the cultivar and lower water availability for the crop during the development cycle, in which it was measured around $390 \mathrm{~mm}$ of rainfall, whereas to BRS Estância cultivar the rainfall regime was $570 \mathrm{~mm}$ during the 
entire crop cycle. The model of the rectangular hyperbola tested to estimate yield losses in the soybean crop due to the density increase of hairy fleabane showed good adjustment, obtaining coefficients of determination of 0.80 and 0.96 for BRS Estância and BMX Turbo cultivars, respectively (Fig. 2).

For the BRS Estância cultivar, the $i$ parameter was estimated by the model in $1.4 \%$, and the maximum estimated yield loss for the a parameter was $82.8 \%$ (Fig. 2). In relation to cultivar BMX Turbo, the parameters $i$ and $a$ were estimated in 25.9 and $95.0 \%$, respectively. The value of $i$ for cultivar BMX Turbo is considered high, which means that the addition of one plant causes a great impact on soybean yield. The segmentation of the curve, by the linear equation between the hairy fleabane densities and soybean yield losses for BRS Estância

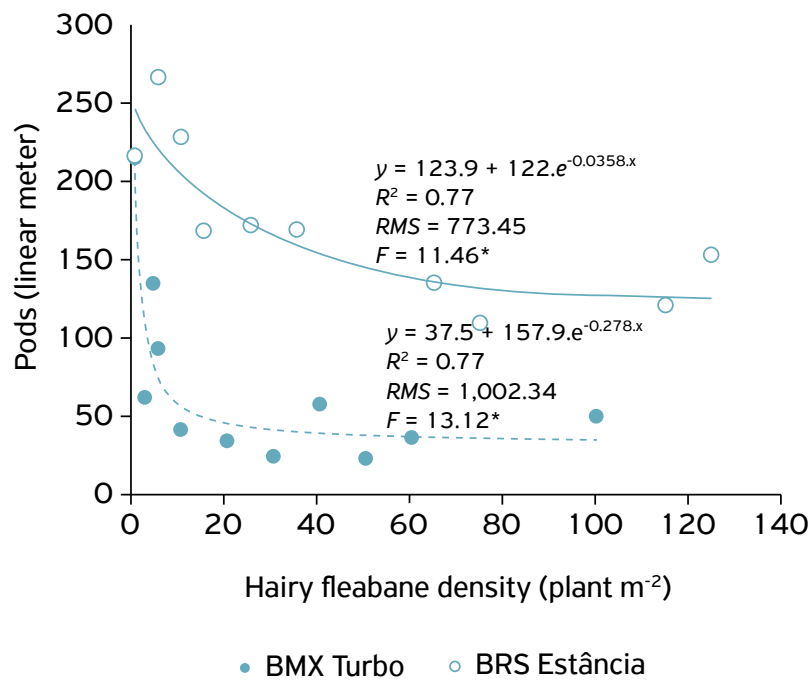

*Significant at $5 \%$ probability.

Figure 1. Number of pods of soybean cultivars BRS Estância and BMX Turbo due to increase of the hairy fleabane density.

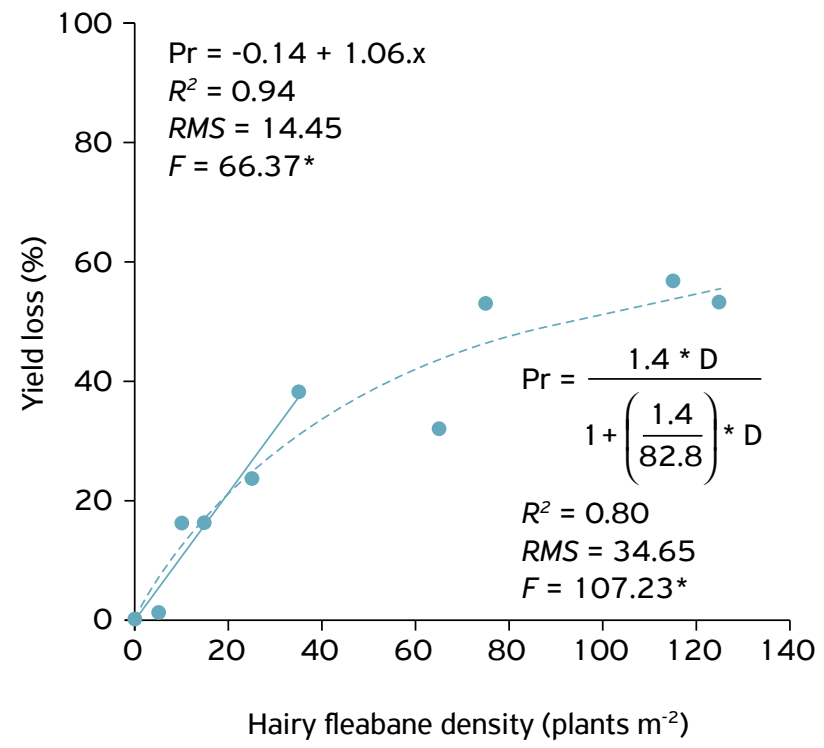

cultivar, allowed to generate linear segment between the densities of 0 to 35 plants $\mathrm{m}^{-2}$ (Fig. 2), being that the increase of each plant of hairy fleabane $\mathrm{m}^{-2}$ increased by $1.06 \%$ the yield loss of soybean grains, corresponding to $30.7 \mathrm{~kg} \mathrm{ha}^{-1}$. For the BMX Turbo cultivar, a segment of the curve was obtained up to the density of 5 plants $\mathrm{m}^{-2}$, and the linear loss was $12.9 \%$, which corresponds to $197.6 \mathrm{~kg} \mathrm{ha}^{-1}$ in each weed plant (Fig. 2).

By using the incline values (b) estimated by the linear model, it is possible to compare the weed interference in the crop, and for the competition with the cultivar BMX Turbo, the $b$ value was about 12 times $(12.9 / 1.06)$ greater than the competition with the BRS Estância cultivar (Fig. 2). The lower interference of the hairy fleabane on the BRS Estância cultivar, we could infer that this cultivar expressed relativity higher competitive ability than BMX Turbo cultivar. This ability could associated to the greater branching of the BRS Estância than BMX Turbo cultivar. Other likely effects are the favorable rainfall to BRS Estância cultivar and size of hairy fleabane on competition observed para BRS Estância cultivar.

Considering that in low weed densities, the yield loss is additive, due to the density increase of competitors, the linear regression models have been shown to be adequate to estimate the yield losses by the presence of each individual competitor added (BAUER et al., 1991). Even when the addition of one single plant causes linear yield losses, there is interspecific competition, which is characterized by the constant production law (RADOSEVICH, 1987). The values of the $i$ and $b$ parameters of the hyperbola and linear equations, respectively, indicate the impact of a hairy fleabane plant on the soybean yield, and present a similarity that explain the effects on the BRS Estância cultivar, which were 1.4 and 1.06, respectively. On the other hand, for the BMX Turbo cultivar, the values of the parameters of the equations that indicate the

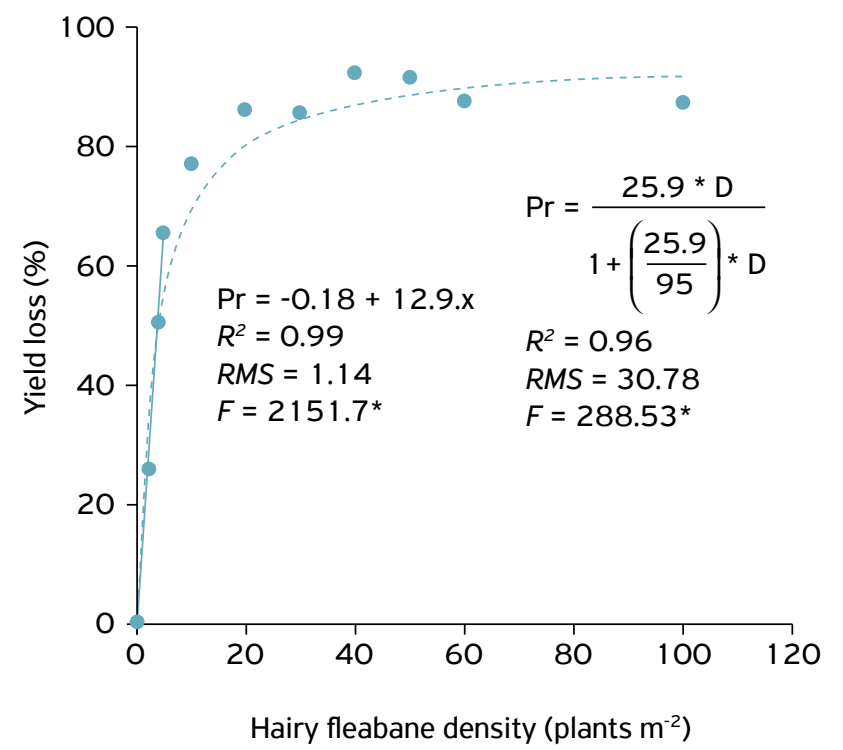

*Significant at $5 \%$ probability.

Figura 2. Soybean yield loss on cultivars BRS Estância and BMX Turbo due to increase of the hairy fleabane density. 
impact of each plant on the yield losses were very different, whereas until to 5 plants $\mathrm{m}^{-2}$ there was an increase of $12.9 \%$ on yield losses, once hyperbole indicated $25.9 \%$ with density up to 100 plants $\mathrm{m}^{-2}$.

The hairy fleabane were highly competitive and had a greater effect on soybean yield, and this effects was reflected when the soybean competition occurred with lower branching soybean, competition with taller hairy fleabane and unfavorable environment. The losses in soybean yield were 56 and 91\% for BRS Estância and BMX Turbo, respectively, in the maximum hairy fleabane densities (Fig. 2). At the time of soybean implantation, in site 2 , the height of the hairy fleabane was $30 \mathrm{~cm}$ tall, so the yield losses as a function of the density increase was more pronounced compared to site 1 . The effect of establishment of weed prior to cultivation exerts greater effects on soybean yield losses (FLECK et al., 2004, TREZZI et al., 2014). Also, the lower cycle of the BMX Turbo cultivar compared to the BRS Estância also contributes to the increase of the $i$ values of the rectangular hyperbole equation (Fig. 1), which represents the impact on yield of the addition of a hairy fleabane plant. These results corroborate with FLECK et al. (2007) that the soybean yield losses of due to the competition with plants that have the same niche cause greater impact on the early cultivar compared to longer cycle cultivars.

ET values for hairy fleabane in the soybean crop ranged from 0.79 to 6.01 for the BRS Estância cultivar, and 0.08 to 0.33 for the BMX Turbo cultivar, in all the simulations tested (Fig. 3). The ET was reduced around 60\% when the increase
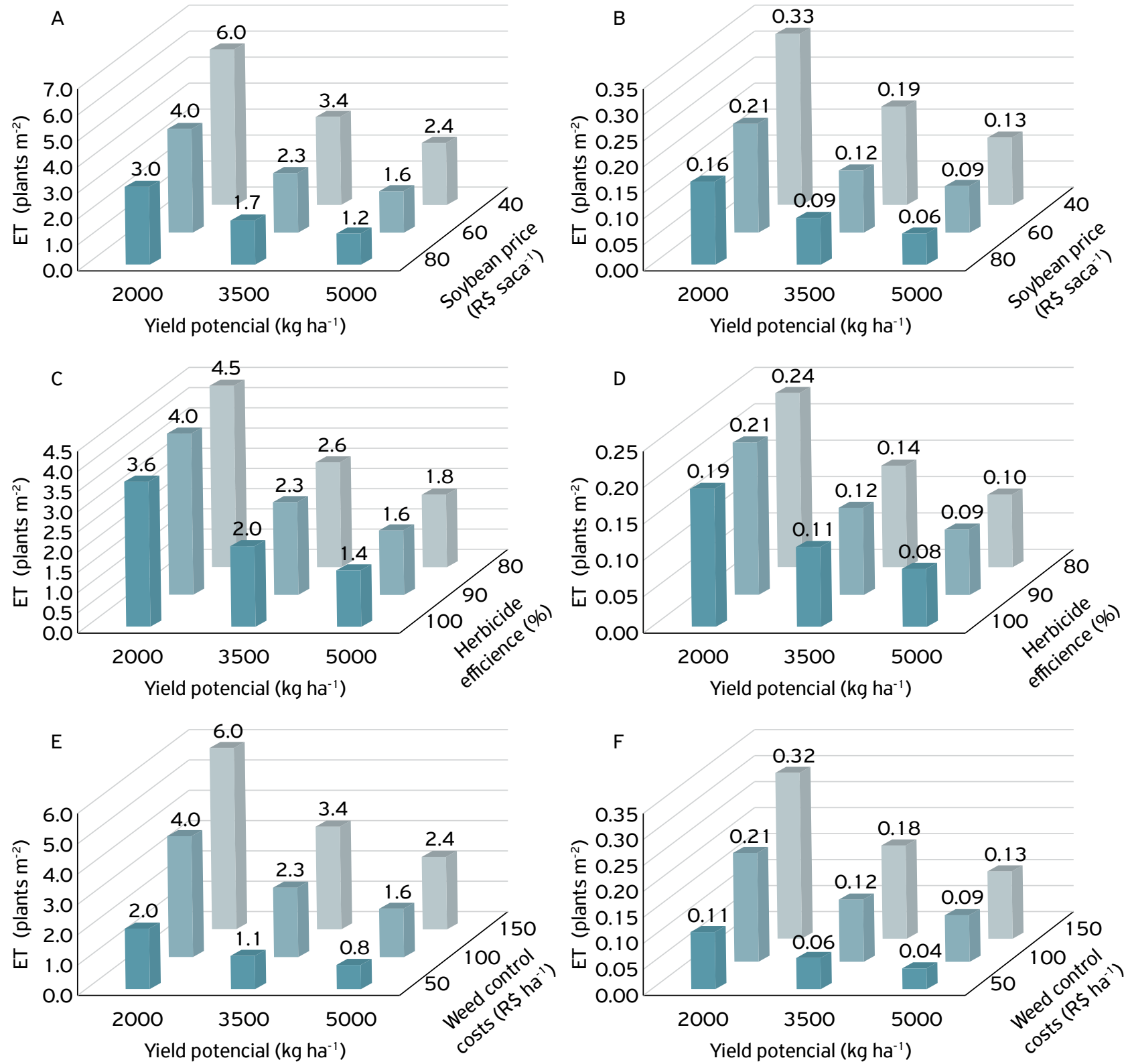

Figure 3. Economic thresholds (ET) of the hairy fleabane on soybean cultivar BRS Estância (A, C and E) and BMX Turbo (B, D and F) as a function of yield potencial, soybean price, herbicide efficiency and weed control cost. 
in the expected soybeans yield from 2,000 to $5,000 \mathrm{~kg} \mathrm{ha}^{-2}$ and $50 \%$ when the value offered by the soybean bag from $\mathrm{R} \$ 40$ to $\mathrm{R} \$ 80$, for both cultivars (Fig. 3A and 3B). Thus, as the crop yield expectation and the soybean grain prices are increased, the weed density will be smaller to ET, which means that with these weed densities the weed control becomes economic profit, each simulated scenario.

The herbicides efficiency is another important component in determining the ET; since as the herbicide efficiency is increased, the ET is reduced (Fig. 3C and 3D). The variation observed for the BRS Estância cultivar was from 1.4 to 4.5 plants $\mathrm{m}^{-2}$, whereas for the BMX Turbo cultivar, lower values were found, varying from 0.08 to 0.24 plants $\mathrm{m}^{-2}$. In this case, the increase in efficiency reduced ET values by $19 \%$ for both cultivars.

In the simulation between grain yield expectation and weed control cost, the variation in hairy fleabane ET ranged from 0.8 to 6.0 and 0.04 to 0.32 plants $\mathrm{m}^{-2}$, to BRS Estância and BMX Turbo cultivars, respectively (Fig. 3E and 3F). The rise in weed control costs from $R \$ 50$ to $R \$ 150 \mathrm{ha}^{-1}$, increased the ET value in the same proportions (200\%). Thus, the increase in weed control costs associated with low crop yield expectations implies an increase in ET, and, in this scenario, control measures, from an economic point of view, should be practiced when the level of weed infestation is higher.

The hairy fleabane density from which it is economically feasible to adopt control measures, in general, is from 0.8 to 6.0 plants $\mathrm{m}^{-2}$ for the BRS Estância cultivar, and 0.04 to 0.33 plant $\mathrm{m}^{-2}$ for the BMX Turbo cultivar. The lowest ET values refer to the simulations with the highest yields, associated with higher soybean prices, high herbicide efficacy and low cost. On the other hand, in the simulations in which the lowest yields were found, the low prices offered by soybean, low herbicide efficiency and high costs characterize the high ET for hairy fleabane plants.

The weed control cost had a significant importance, since the costs of herbicide application can be easily manipulated by the producers, amortizing the weed control costs. In the tested scenarios, the increase in weed control costs, considering the sprayers and herbicides prices, tends to increase ET, and larger hairy fleabane density is necessary to justify control.

The results of the study evidenced the magnitude of the impact of the increase of the hairy fleabane density on soybean grain yield, and the injury was most evidenced when combining genotype effects, stage of development of hairy fleabane and / or environment plants. As more advanced the development of hairy fleabane at the moment of the implantation of the soybean crop, greater are the yield losses, due to the effects of the competition and the difficulty of management these plants (TREZZI et al., 2014). The management of the glyphosate resistant hairy fleabane should be carried out within a system that includes an integrated management action at reducing the impact on soybean cultivation, aiming at reducing germination, density size of plants and production of hairy fleabane seeds. In this way, the implantation of cover crops presents as an alternative in reducing the germinative flow, of the density and height of the hairy fleabane plants. Among the weed management, crop rotation is an alternative to the reduction of the plant density, since it facilitates the herbicides rotation. Covering plants or predecessor crops have a potential for reduction on germination and development of the hairy fleabane, since they are positive photoblastic seeds (VIDAL et al., 2007; YAMASHITA; GUIMARÃES, 2011). The cultivation of wheat and black oats are important alternatives for reducing the hairy fleabane density, as well as reducing plant height (PAULA et al., 2011). The shading of the weed, by cover crop or straw residues, causes the plants to receive basically reflected light and of lower intensity, which will cause a gradual decrease of the photosynthetic rate and consequently a reduction of the same growth. In order to maximize weed control, the use of herbicides in pre-sowing soybean management is associated with the hairy fleabane's cultural management (LAMEGO et al., 2013). The effectiveness of herbicides on glyphosate resistant hairy fleabane is dependent on the stage of weed development, which is a fundamental element for the success of herbicide control (BRESSANIN et al., 2014).

The hairy fleabane management should occur before the implantation of the soybean. If there is no success in the hairy fleabane management, it is possible to complement the control with soybean post-emergence herbicides, although in this modality it is less likely to occur due to the low efficiency of the herbicides, which results mainly from the stage of development of the plants (PAULA et al., 2011; BRESSANIN et al., 2014). Another factor related to the interactions between herbicides and hairy fleabane development stages is the regrowth capacity when herbicides are applied on plants of advanced stages of development (MOREIRA et al., 2007). Thus, in smaller plants the dose and frequency of application of herbicides could be reduced, which could minimize the environmental impact of pesticides and reduce production costs.

The difficulty of using the ET by the farmers is given to the extent that it is not known what crop yield will express. However, it must be taken into account the expected yield, according to the crop investment and historical data in the crop yield (KALSING; VIDAL, 2010).

Based on historical grain prices, yields and herbicide efficiency, the ET can aid in weed management more economically, compensating the farmer more efficiently. Similar studies verified a great variation in the ET for hairy beggartick sand arrowleaf sida species in the soybean, with ET ranging from 0.4 to 33 and 2 to 50 , respectively (RIZZARDI et al., 2003; FLECK et al., 2002). It is pointed out that the ETs reflect the direct damage caused by the weed, and that the effect of the uncontrolled density on seed production should be considered. 
The expectations of soybean yield vary according to the edaphoclimatic conditions, mainly due to the distribution of the rainfalls during the crop cycle, since in years characterized with rainfalls above the average one is likely to reach higher production. Another factor that influences the increase in the expectation of crop yield is the financial investment by the farmer, with the use of technologies such as the cultivars that are more productive and adapted to the region, use of precision agriculture and pest and diseases management. Already, the regulation of the price of soybean is composed of a relation between world stocks and the equilibrium between supply and demand.

In the simulations tested in which soybean yield potential, grain prices and herbicide efficiency were increased, ET values decreased. Thus, in a field that high technological level is used in the soybeans production with high yield expectations, the weed density will be smaller to justify the economic application of herbicides. In turn, as the weed control costs are increased, the ETs arise at the same proportions, demonstrating that the adoption of control measures is justified only when the hairy fleabane densities are higher.

As the ETs in this study considered only one growing season, the effects of the increase of the seed bank were not assumed. Plants of the Conyza genus are able to produce large amounts of seeds per plant, besides being very easy to disperse at great distances (DAUER et al., 2009). The species C. canadensis can produce around 700,000 seeds per plant, depending on the conditions under which it is being grown
(SHRESTHA et al., 2010). Therefore, increases in the weed seed bank may occur, compromising long-term profitability (DOYLE; STYPA, 2004; BLACKSHAW et al., 2006).

The difficulties and restrictions inherent in the use of $\mathrm{ET}$ as a tool for weed management should serve as an alert, so that its adoption is only feasible in crop situations that integrate other weed management practices such as the use of crop rotation, adequate arrangement of plants, use of more competitive cultivars and applications of efficient herbicides and doses (RIZZARDI et al., 2003).

\section{CONCLUSIONS}

Based on these results, the interference of the one hairy fleabane plant $\mathrm{m}^{-2}$ decreased soybean yield by 1,4 and $25.9 \%$ to BMX Turbo and BRS Estância cultivar.

Soybean yield and ETs were lower for the BMX Turbo cultivar compared to the BRS Estância cultivar, which can be attributed to the genotype, competitive ability, and stage of development of the hairy fleabane and/or environment.

Increases in crop yield, soybean prices and herbicide efficiency reduced ET, indicating that control measures should be adopted when the hairy fleabane density is low. When the control cost is high, there is an increase in the ET, indicating that it is more economical to control the hairy fleabane plants only when in a larger density.

| | | | | | | | | | | | | | | | | | | | | | | | | | | | | | | | | | | | | | | | | | | | | | | | | | | | | | | | | | | | | | | | | | | | | | | | | | | | | | | | | | | | | | | | | | | | | | | | | | | | | | | | | | | | | | | | | | | | | | | | | | | | | | | | | | | | | | | | | | | | | | | | | | | | | | | | | | | | | | | | | | | | | | | | | | | | | | | | | | | | | | | | | | | | | | | | | | | | | | | | | | | | | | | | | | REFERENCES

AGROLINK. Cotações. 2016. Available from: <https://www. agrolink.com.br/cotacoes/graos/soja/soja-em-grao-sc-60kg>. Accessed on: Feb. 12016.

BAUER, T.A.; MORTENSEN, D.A.; WICKS, G.A.; HAYDEN, T.A.; MARTIN, A.R. Environmental variability associated with economic thresholds for soybeans. Weed Science, Lawrence, v.39, n.4, p.564-569, 1991 .

BIANCHI, M.A.; FLECK, N.G.; FEDERIZZI, L.C. Características de plantas de soja que conferem habilidade competitiva com plantas daninhas. Bragantia, Campinas, v.65, n.4, p.623-632, 2006.

BLACKSHAW, R.E.; O'DONOVAN, J.T.; HARKER, K.N.; CLAYTON, G.W.; STOUGAARD, R.N. Reduced herbicide doses in field crops: a review. Weed Biology Management, Malden, v.6, n. 1, p. 10-1 1, 2006.

BRESSANIN, F.N.; JAYME NETO, N.; MARTINS, J.F.; MARTINS, J.F.; ALVES, P.L.C.A. Controle de biótipos resistentes de Conyza bonariensis com glyphosate + clorimuron-etílico em função do estádio de desenvolvimento. Revista Brasileira de Herbicidas, Londrina, v.13, n. 1, p.68-72, 2014.
COMPANHIA NACIONAL DE ABASTECIMENTO (CONAB). Séries históricas. Brasília, 2016. Available from: <http://www.conab. gov.br/conteudos.php?a=1252>. Accessed on: Feb. 12016.

COUSENS, R. An empirical model relating crop yield to weed and crop density and a statistical comparison with other models. Journal of Agricultural Sciences, Toronto, v. 105, n.3, p.513-521, 1985.

DAUER, J.T.; MORTENSEN, D.A.; LUSCHEI, E.C.; ISARD, S.A.; SHIELDS, E.; VAN-GESSEL, M.J.Conyza canadensis seed ascent in the lower atmosphere. Agricultural and Forest Meteorology, Connecticut, v.149, n.3-4, p.526-534, 2009.

DOYLE, P.; STYPA, M. Reduced herbicide rates: a Canadian perspective. Weed Technology, Fayetteville, v.18, n.4, p. $1157-1165,2004$.

FLECK, N.G.; LAMEGO, F.P.; SCHAEDLER, C.E.; FERREIRA, F.B. Resposta de cultivares de soja à competição com cultivar simuladora da infestação de plantas concorrentes. Scientia Agraria, Curitiba, v.8, n.3, p.213-218, 2007. 
FLECK, N.G.; RIZZARDI, M.A.; AGOSTINETTO, D. Nível de dano econômico como critério para tomada de decisão no controle de guanxuma em soja. Planta Daninha, Viçosa, v.20, n.3, p.421-429, 2002.

FLECK, N.G.; RIZZARDI, M.A.; AGOSTINETTO, D.; BALBINOT JR., A.A. Interferência de picão-preto e guanxuma com a soja: efeitos da densidade de plantas e épocas relativa de emergência. Ciência Rural, Santa Maria, v.34, n. 1, p.41-48, 2004.

GHEREKHLOO, J.; NOROOZI, S.; MAZAHERI, D.; GHANBARI, A.; GHANNADHA, M.R.; VIDAL, R.A.; DE PRADO, R. Multispecies weed competition and their economic threshold on the wheat crop. Planta Daninha, Viçosa, v.8, n.2, p. 239-246, 2010.

KALSING, A.; VIDAL, R.A. Nível de dano econômico aplicado à herbologia: revisão. Pesticidas: Revista de Ecotoxicologia e Meio Ambiente, Curitiba, v.20, n.1, p.43-56, 2010.

LAMEGO, F.P.; KASPARY, T.E.; RUCHEL, Q.; GALLON, M.; BASSO, C.J.; SANTI, A.L. Manejo de Conyza bonariensis resistente ao glyphosate: coberturas de inverno e herbicidas em pré-semeadura da soja. Planta Daninha, Viçosa, v.31, n.2, p.433-442, 2013.

LAZAROTTO, C.A.; FLECK, N.G.; VIRAL, R.A. Biologia e ecofisiologia de buva (Conyza bonariensis e Conyza canadensis). Ciência Rural, Santa Maria, v.38, n.3, p.852-860, 2008.

LINDQUIST, J.L.; KROPFF, M.J. Applications of an ecophysiological model for irrigated rice (Oryza sativa) - Echinochloa competition. Weed Science, Lawrence, v.44, n. 1, p.52-56, 1996.

MOREIRA, M.S.; NICOLAI, M.; CARVALHO, S.J.P.; CHRISTOFFOLETI, P.J. Resistência de Conyza canadensis e $C$. bonariensis ao herbicida glyphosate. Planta Daninha, Viçosa, v.25, n. 1, p. 157-164, 2007.

PAULA, J.M.; VARGAS, L.; AGOSTINETTO, D.; NOHATTO, M.A. Manejo de Conyza bonariensis resistente ao herbicida glyphosate. Planta Daninha, Viçosa, v.29, n. 1, p.217-227, 2011.

RADOSEVICH, S.R. Methods to study interactions among crops and weeds. Weed Technology, Fayetteville, v.1, n.3, p.190-198, 1987.
RIZZARDI, M.A.; FLECK, N.G.; AGOSTINETTO, D. Nível de dano econômico como critério para controle de picão-preto em soja. Planta Daninha, Viçosa, v.21, n.2, p.273-282, 2003.

SHRESTHA, A.; HANSON, B.D.; FIDELIBUS, M.W.; ALCORTA, $M$. Growth, phenology, and intraspecific competition between glyphosate-resistant and glyphosate-susceptible hairy flabanes (Conyza canadensis) in the San Joaquin Valley of California. Weed Science, Lawrence, v.58, n.2, p.147-153, 2010.

SILVA, D.R.O.; VARGAS, L.; AGOSTINETTO, D.; MARIANI, F. Glyphosate-resistant hairy fleabane competition in RR soybean. Bragantia, São Paulo, v.73, n.4, p.451-457, 2014.

TREZZI, M.M.; BALBINOT JR., A.A.; BENIN, G.; DEBASTIANI, F.; PATEL, F.; MIOTTO JR., E. Competitive ability of soybean cultivars with horseweed (Conyza bonariensis). Planta Daninha, Viçosa, v.31, n.3, p.543-550, 2013.

TREZZI, M.M.; VIDAL, R.A.; PATEL, F.; MIOTTO JR., E.; DEBASTIANI, F.; BALBINOT JR., A.A.; MOSQUEN, R. Impact of Conyza bonariensis density and establishment period on soyabean grain yield, yield components and economic threshold. Weed Research, Malden, v.55, n. 1, p.34-41, 2014.

VARGAS, L.; BIANCHI, M.A.; RIZZARDI, M.A.; AGOSTINETTO, D.; DAL MAGRO, T. Buva (Conyza bonariensis) resistente ao glyphosate na região sul do Brasil. Planta Daninha, Viçosa, v.25, n.3, p.573-578, 2007.

VIDAL, R.A.; KALSING, A.; GOULART, I.C.G.R.; LAMEGO, F.P.; CHRISTOFFOLETI, P.J. Impacto da temperatura, irradiância e profundidade das sementes na emergência e germinação de Conyza bonariensis e Conyza canadenses resistentes ao glyphosate. Planta Daninha, Viçosa, v.24, n.2, p.309-315, 2007.

YAMASHITA, O.M.; GUIMARÃES, S.C. Germinação de sementes de Conyza canadensis e Conyza bonariensis em diferentes condições de temperatura e luminosidade. Planta Daninha, Viçosa, v.29, n.2, p.333-342, 2011. 